\title{
Sex Difference in Bottlenose Dolphin Sightings during a Long-term Bridge Construction Project
}

\author{
Ann Weaver ${ }^{*}$ \\ ${ }^{1}$ Good-natured Statistics Consulting, LLC \\ *Corresponding author (Email: annstats54@gmail.com) \\ Citation - Weaver, A. (2015). Sex differences in bottlenose dolphin sightings during a long-term bridge \\ construction project. Animal Behavior and Cognition, 2(1), 1-13. doi: 10.12966/abc.02.01.2015
}

\begin{abstract}
Almost nothing is known about the effect of long-term bridge construction on free-ranging bottlenose dolphins (Tursiops truncatus). The species' natural history predicts that there should be sex differences in reaction to construction because bottlenose dolphins show sex differences in most of their behaviors. A 5-year bridge construction project over a narrow but important dolphin corridor at John's Pass tidal inlet, St. Petersburg FL, brought chronic environmental changes. The purpose of this 8 -year study was to determine if bridge construction was associated with changes in dolphin sightings. The sex difference hypothesis was tested with a comparison of sighting probabilities before, during and after bridge construction. Sighting probabilities were generated for 68 adults seen $n=6504$ times during $N=951$ small-boat surveys of the 6.5-mile estuarine study area, documented with photo identification June 2005-December 2012. The sex difference hypothesis was supported with a significant interaction between construction and gender. Female sightings showed a significant linear decline across construction. Male sightings did not change across construction. The main conclusion is that adult males and females may react differently to habitat changes associated with anthropogenic activities. Sex differences in environmental monitoring and vigilance associated with maternal behavior may have played a role. This is the first report on John's Pass dolphins that evaluates changes in their behavior during a major construction project across a narrow but important dolphin corridor.
\end{abstract}

Keywords - Resident bottlenose dolphins, Coastal construction, Sighting patterns, Gender differences, Anthropogenic threats

The behavior of free-ranging bottlenose dolphins is characterized by extreme variability, which stems in part from sex differences (Connor, Wells, Mann, \& Read, 2000; Shane, Wells, \& Würsig, 1986). Males and females show sex differences in home range size, habitat use, social associations, foraging specializations, day range, seasonal patterns, reproductive strategies, social development and even age at weaning. The aim of this research was to test the sex difference hypothesis to see if it explained sighting patterns in free-ranging adult bottlenose dolphins before, during and after a long-term bridge replacement project over an important narrow dolphin corridor John's Pass on the west central coast of Florida that connects the Gulf of Mexico and the Intra-Coastal Waterway. Although a sex difference is predicted by bottlenose dolphin natural history, nothing is known about how sex differences might interact with longterm construction projects in key areas of dolphin habitat.

Data on cetacean responses to marine construction are sparse, and more data are sorely needed (Würsig \& Evans, 2001) because current findings report both conspicuous and subtle responses. Noise generated from maritime industrial, military and construction activities disrupts the naturally occurring behavior of numerous species, including beluga whales and narwhals (Cosens \& Dueck, 1993; Finley, Miller, Davis, \& Greene, 1990; Lesage, Barrette, Kingsley, \& Sjare, 1999; LGL \& Greeneridge, 1986), 
bowhead whales (Richardson, Greene, Malme, \& Thomson, 1995), gray whales (Malme \& Miles, 1985) and sperm whales (Bowles, Smultea, Würsig, DeMaster, \& Palka, 1994). In some cases, the disruption is catastrophic, as for Cuvier's beaked whales (Frantzis, 1998). Alternatively, other behavioral responses to anthropogenic activities are subtle and difficult to detect (Samuels \& Tyack, 2000; Whitehead, Reeve, \& Tyack, 2000). These include increased swimming speeds or vocal rates, avoidance, potential compromise of orientation abilities, more frequent entrapment in fishing nets and changes in habitat use (Buckstaff, Wells, Gannon, \& Nowacek, 2013; Finneran et al., 2000; Moore, Wells, Gannon, \& Nowacek, 2006; Richardson, Fraker, Würsig, \& Wells, 1985; Schick \& Urban, 2000; Sofie, van Parijs, \& Corkeron, 2001; Todd, Stevick, Lien, Marques, \& Ketten, 1996; Würsig, Greene, \& Jefferson, 2000).

The relationship between anthropogenic activities and cetaceans can be difficult to detect for several reasons. Cetaceans are difficult to study because most of their activities are underwater (Connor et al., 2000). Few studies of anthropogenic activities are able to employ a before-during-after design (Buckstaff et al., 2013; Richardson et al., 1985; Todd et al., 1996) because such designs either require forewarning about construction or an existing database of baseline behavior. Most studies therefore result in post hoc analyses only, which provide more tenuous evidence than before-after construction comparisons. Responses that appear to be subtle could also emerge if different patterns of responses that were related to sex differences cancelled each other out during data analysis. Greater knowledge about the relationship between anthropogenic activities and cetaceans is clearly needed (Würsig \& Evans, 2001), and examination of the hypothesized role of sex differences relative to coastal construction is an important contribution.

A long term, geographically localized bridge construction project over John's Pass provided the opportunity to document free-ranging bottlenose dolphin behavior before, during and after bridge construction. John's Pass dolphins are part of the Tampa Bay stock (Fulling, Mullin, \& Hubard, 2007; Hubard \& Schwartz, 2002) although no data exist on them outside of the current study. Due to proximity and similar ecological conditions, the Sarasota model (Scott, Wells, \& Irvine, 1990; Reynolds, Wells, \& Eide, 2000; Wells, 2003) is a good model for John's Pass dolphins. Behavioral and genetic studies (Duffield \& Wells, 2002; Sellas, Wells, \& Rosel, 2005) have shown that, although concentrations of certain haplotypes suggest a degree of autonomy between the Sarasota and South Tampa Bay community, dolphin communities in the Tampa Bay-Sarasota waterways, which include John's Pass, interact socially as well as reproductively. This results in a "stepping stone" model of population structure that facilitates genetically significant exchange across communities (Duffield \& Wells, 2002). The dolphins that use the John's Pass study area behave similarly to Sarasota dolphins in many ways: Males and females in both areas show differences in habitat use, social associations, foraging specializations, day range, seasonal patterns, social development and age at weaning (Weaver, unpub, data). It is currently unknown whether John's Pass dolphins show home range sizes or reproductive strategies that are similar to Sarasota dolphins. However, the bulk of the similarities justifies using Sarasota as a model.

Pertinent to the current study is that Sarasota dolphins are year-round, long-term [italics mine] residents; the dolphin community is largely maintained by female philopatry (Duffield \& Wells, 2002). Dolphin genetic studies show that both sexes of bottlenose dolphins in the Tampa Bay-Sarasota dolphin communities exhibit a significant level of site philopatry (Sellas et al., 2005) and very low levels of immigration and emigration (2 - 3\%, Wells \& Scott, 1990). Additional studies of inshore dolphin communities along the Gulf of Mexico have documented similar long-term year-round use of waterways by core groups of resident dolphins as well (Fazioli, 1999; Wells, Bassos, et al., 1996; Wells, Urian, et al., 1996; Würsig \& Lynn, 1996). However, the sexes also show key differences in habitat use and occurrence patterns. Females share smaller core areas with other females. Sarasota female bands have shown compositional integrity for over 25 years (Connor et al., 2000). In contrast, males range the entire length of the $40 \mathrm{~km}$ Sarasota study area more frequently than females do, and may disappear entirely for months.

If John's Pass dolphins show similar long-term residency patterns, the Sarasota model and above studies argue that systematic declines in occurrence are not an intrinsic part of bottlenose dolphin natural history. However, coastal bottlenose dolphins will shift location if environmental changes are substantial enough. A community of coastal bottlenose dolphins off San Diego extended their home range $600 \mathrm{~km}$ by 
penetrating in Monterey Bay in probable response to the 1982 - 1983 warming El Niño event (Wells et al., 1990). The shift was apparently permanent because these individuals inhabited Monterey Bay for at least the next ten years (Feinholz, 1995). Research questions addressed in this report are: Was the five years of chronic environmental change from bridge construction substantial enough to elicit a long-term location shift among John's Pass dolphins? If so, did they show a sex difference?

\section{Method}

\section{Bridge Construction}

John's Pass Bridge construction lasted 4.8 years, from January 252006 - October 10 2010. The deck surface of the new bridge is $14,750 \mathrm{~m}^{2}$ (397 m long, $31 \mathrm{~m}$ wide, two $12 \mathrm{~m}$ lanes for road traffic in each direction are outfitted with two $32 \mathrm{~m}$ bascule arms).

Construction was geographically localized because John's Pass is narrow, just $183 \mathrm{~m}$ wide, and exposed the adjacent marine environment to extensive acute and chronic changes (Figure 1). Construction involved removing the old bridge and constructing the new bridge. Acute construction-related changes were separate percussive blasts to demolish existing cement bastions (8/3/2006, 11/20/2008). Chronic construction-related changes included increased levels of noise, illumination, vessel traffic and various large floating structures that were not there normally (Figure 1). The process of removing the old bridge and constructing the new bridge created changes to the local habitat, e.g., pounding several different sets of pilings as construction barge moorings on the north and south sides of the pass on the east IntraCoastal Waterway side and also on the west Gulf of Mexico side of the construction site (Figure 1). New cement bastions were set wider apart and potentially altered turbidity and current patterns (Becker \& Ross, 1999). Baseline observations before construction began showed that dolphins used John's Pass daily as an important corridor between the Gulf of Mexico and Intra-Coastal Waterway. Exposure to construction was unavoidable if they continued to use the narrow $183-\mathrm{m}$ pass. To avoid direct exposure to construction, they had to travel $5.95 \mathrm{~km}$ south to Blind Pass, $6.76 \mathrm{~km}$ south to Pass-a-Grille Pass, or 23.49 $\mathrm{km}$ north to Clearwater Harbor.

\section{Research Design}

The research design was a before-during-and-after construction time series. The before construction phase was July 20, 2005 - January 24, 2005. The during construction phase was January 25, 2006 - October 10, 2010. The after construction phase was October 11, 2010 - December 31, 2012. My NOAA permit for construction data collection started in summer 2005 so there are no spring data for the before construction phase. Therefore, the data are for summer (June - August), fall (September November) and winter data (December - February; seasons were defined by Shane et al., 1986).

Boat surveys. The study area is a narrow $6.5 \mathrm{sq} \mathrm{mi} \mathrm{section} \mathrm{of} \mathrm{the} \mathrm{Boca} \mathrm{Ciego} \mathrm{Intra-Coastal}$ Waterway with good visual access to both shorelines (Figure 2). The transect route ran between channel markers. Sighting effort was continuous and began when the boat left the dock. Two observers were on board; AW collected data and a second person drove the boat. It was possible that dolphins were missed. Morning surveys of the study area were conducted $2-3$ times weekly starting within two hours of dawn by small boat (19' Proline, Yamaha $115 \mathrm{hp}$ outboard). Surveys were consistent in starting at the home dock, continued to John's Pass, continued along the west side of John's Pass tidal deltas to the north end of the study area, returned over the same route about half way but then continued along the east side of John's Pass tidal deltas to the southern end of the study area, and then to the home dock (Figure 2). 

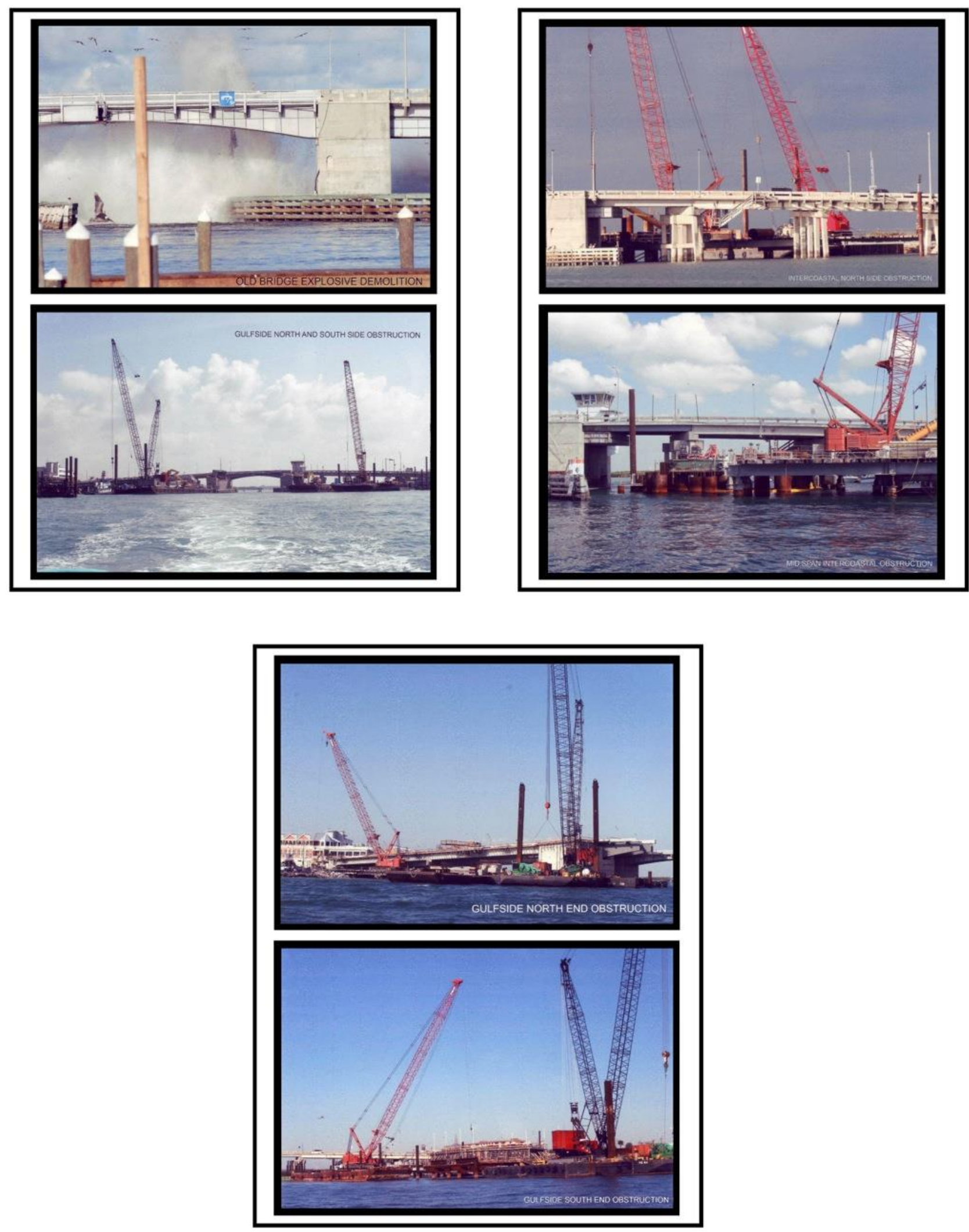

Figure 1. Construction images. 


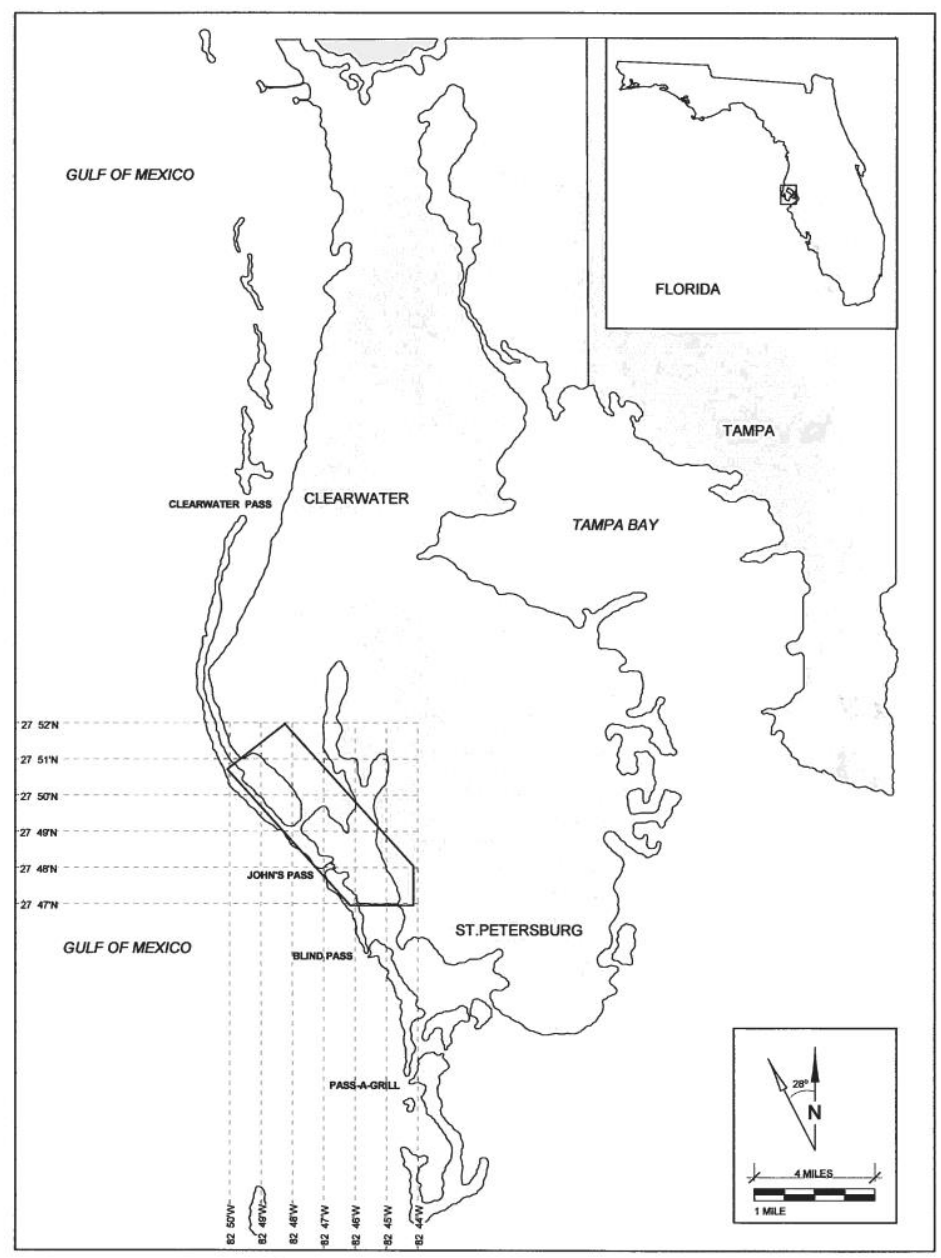

Figure 2. John's Pass study area, north end N $27^{\circ} 49.949$, W $82^{\circ} 49.491$; south end N $27^{\circ} 46.333$, W 82 45.215 . The study area is a $6.5 \mathrm{sq}$ mi portion of a continuous estuarine ICW Boca Ciega Bay system. John's Pass is located at N 27 47.109 , W $82^{\circ}$ 46.803. There are about $10 \mathrm{mi}$ of coastline for every mile of water (coastline $62.88 \mathrm{mi}$ long), created by numerous waterways and 51 cul-de-sac "fingers" of water hardened by seawalls. Average water depth is $7 \mathrm{ft}$; the majority of the study area ranges from less than $1 \mathrm{ft}$ off sandbars to depths of about $22 \mathrm{ft}(6 \mathrm{~m})$. John's Pass is the deepest area, about 20-40 ft deep (6-12 m).

Photo ID. The route was run until dolphins were found. Observations were focal group follows (Mann, 1999; Müeller, Boutiere, Weaver, \& Candelon, 1998) that generally lasted 15 - 30 min per dolphin group or until several pictures of every dolphin had been obtained. After observation of a dolphin group ended, the survey was resumed along the transect line until the entire study area was surveyed. Surveys lasted $2 \mathrm{hrs}$ when dolphins were not encountered and up to $8 \mathrm{hrs}$ when they were. Dolphin sightings were documented with the mark-recapture technique of photo-identification (hereafter photo ID, Hammond, Mizroch, \& Donovan, 1990; Würsig \& Würsig, 1977). Marks were naturally occurring shapes, notches and scars on dorsal fins that identified individual dolphins. Recaptures were photographs. Two cameras were used. Through February 2006, photo ID data were collected on $200-400$ ISO color film with a Canon EOS $35 \mathrm{~mm}$ single-lens camera with $35-135 \mathrm{~mm}$ and 100-300 mm zoom lenses. Since February 2006 to the present, photo ID data were collected as digital images with a Canon EOS 20D or 50D high-speed digital camera with a $70-200 \mathrm{~mm}$ zoom lens. AW counted and photographed dolphins throughout observation. At the end of each survey, AW sorted dorsal fin photos by eye and quality (Urian, Hohn, \& Hansen, 1999) rather than processed photos with Finbase or Finscan software. No second matcher verified matches. The best photos of each dolphin were dated, labeled and stored by 
survey, $N=313$ identified dolphins to date. Approximately 75,000 photo ID photos have been saved in the photographic database to date; 5000 of these are hard copy photos and the rest are digital images.

Identifying gender. Determining the sex of individual dolphins is hampered by lack of obvious sexual dimorphism (Connor et al., 2000). In John's Pass, the dolphins have been studied $2-3$ times a week for ten years. Dolphins of known gender are the dolphins that have been encountered so often in the study area that they are resident dolphins and their gender has been identified. Adult females were large dolphins seen repeatedly with dependent calves. Adult males were large dolphins seen with erections. All dolphins in this report are identified by ID numbers and can be viewed in the NOAA OBIS Seamap Gulf of Mexico Dolphin Identification System (GoMDIS). John's Pass dolphin age-sex class population proportions are 0.26 for adult males, 0.29 for adult females, 0.24 for adults of unknown gender, 0.03 for male calves, 0.03 for female calves and 0.13 for calves of unknown gender.

Statistical analysis, variables, and hypotheses. A mixed between-within $2 \times 3$ repeated measures ANOVA was conducted with SPSS v 22 statistical software. Significance was set at $\alpha=0.05$. The between group factor was gender with two levels: adult male and adult female. The within group factor was construction phase with three levels: before, during and after construction. Dunnett's post hoc was used because it positions one level as the control against which other levels are compared; the before construction phase was the control, the during construction and after construction data were compared to it. The dependent variable was the probability of sighting an individual dolphin per construction phase. Sighting probabilities were calculated as the number of times that each dolphin was seen during each construction phase divided by the number of surveys conducted during that phase; each dolphin had a sighting probability for each before, during and after construction phase. Sighting probabilities were generated for adult dolphins that were 1) identified during pilot work and 2) seen during all three construction phases, $n=68$ out of the 313 identified dolphins to date. The null hypotheses were that there was no statistically significant gender by construction interaction effect or statistically significant main effects of construction phase or gender on sighting probabilities. The alternative hypothesis was that sighting probabilities would change across construction and/or differ by gender.

\section{Results}

Data were collected from the years 2005-2012, 10-12 surveys/month for 85 months, 22-43 surveys/season for 29 seasons, $n$ before $=100$ surveys, $n$ during $=622$ surveys, $n$ after $=165$ surveys. A subset of 68 adult dolphins met the inclusion criteria; altogether, they were seen $N=6504$ times and are high site fidelity dolphins, $n=28$ males, $n=40$ females. During this time, $30(75 \%)$ of the females showed active mothering with $1-4$ calves, 3 females $(8 \%)$ were quiescent and 7 females (18\%) were nullipares. Sighting probabilities were screened for data entry errors, normality, linearity, homogeneity of variance and outliers, and no substantial deviations were found.

Table 1 shows that male sighting probabilities remained constant across construction but female sighting probabilities changed across construction. Before construction, the mean sighting probability for females was more than twice the mean sighting probability for males. During construction, the mean sighting probability for females approached the mean sighting probability for males but was still higher. After construction, the mean sighting probability for females did not differ from the mean sighting probability for males. For both sexes, the minimum sighting probability was $p=0.01$ in all construction phases. The maximum sighting probability showed a sex difference. The maximum for males was $p=$ 0.19 during construction but remained relatively consistent across the three phases of construction. The maximum for females $p=0.43$ before construction; that is, females were encountered up to almost half of all of the surveys before construction. But these did not remain consistent across construction, declining from $p=0.43$ before construction to $p=0.18$ after construction. The latter maximum sighting probability was comparable to the maximum male sighting probability. 
Table 1

Descriptive Statistics of Sighting Probabilities of High Site Fidelity Bottlenose Dolphins across Three Phases of Construction, Adult Males $n=28$, Adult Females $n=40$

\begin{tabular}{|c|c|c|c|c|c|c|c|}
\hline \multirow{2}{*}{$\begin{array}{l}\text { Gender } \\
\text { Construction Phase }\end{array}$} & & \multicolumn{3}{|c|}{ Males } & \multicolumn{3}{|c|}{ Females } \\
\hline & & Before & During & After & Before & During & After \\
\hline Mean & & 0.05 & 0.07 & 0.05 & 0.12 & 0.09 & 0.06 \\
\hline Standard Deviation & & 0.05 & 0.05 & 0.04 & 0.11 & 0.06 & 0.05 \\
\hline Standard Error & & 0.008 & 0.009 & 0.008 & 0.018 & 0.011 & 0.008 \\
\hline 95\% Confidence Interval & LB & 0.04 & 0.05 & 0.03 & 0.09 & 0.07 & 0.04 \\
\hline for Mean & UB & 0.07 & 0.09 & 0.06 & 0.16 & 0.11 & 0.08 \\
\hline Minimum & & 0.01 & 0.01 & 0.01 & 0.01 & 0.01 & 0.01 \\
\hline Maximum & & 0.15 & 0.19 & 0.15 & 0.43 & 0.26 & 0.18 \\
\hline
\end{tabular}

$\mathrm{LB}=$ Lower bound for the CI UB = Upper bound for the CI

The ANOVA supported the sex difference hypothesis. There was a significant interaction between construction phase and gender, Wilks Lambda $=0.87, F(2,65)=4.93, p=0.01$. This significant interaction indicated that sighting probabilities differed as a function of both construction phase and gender. The effect size statistic partial eta squared $=0.13$, indicating that the interaction effect between construction and gender was strong.

Figure 3 illustrates the source of the significant interaction between gender and construction phase. The dashed line illustrates the statistically significant linear decline in mean sighting probabilities across construction among females. Dunnett's showed that female before-during probabilities did not differ significantly, $p=0.15$. But females were seen significantly less after construction compared to before construction, mean difference $=-0.11, p=0.001$. In contrast, the solid line in Figure 3 shows that male sighting probabilities did not change across construction, Dunnett's test: before-during probabilities were non-significant, $p=0.25$, before-after probabilities were non-significant, $p=0.82$.

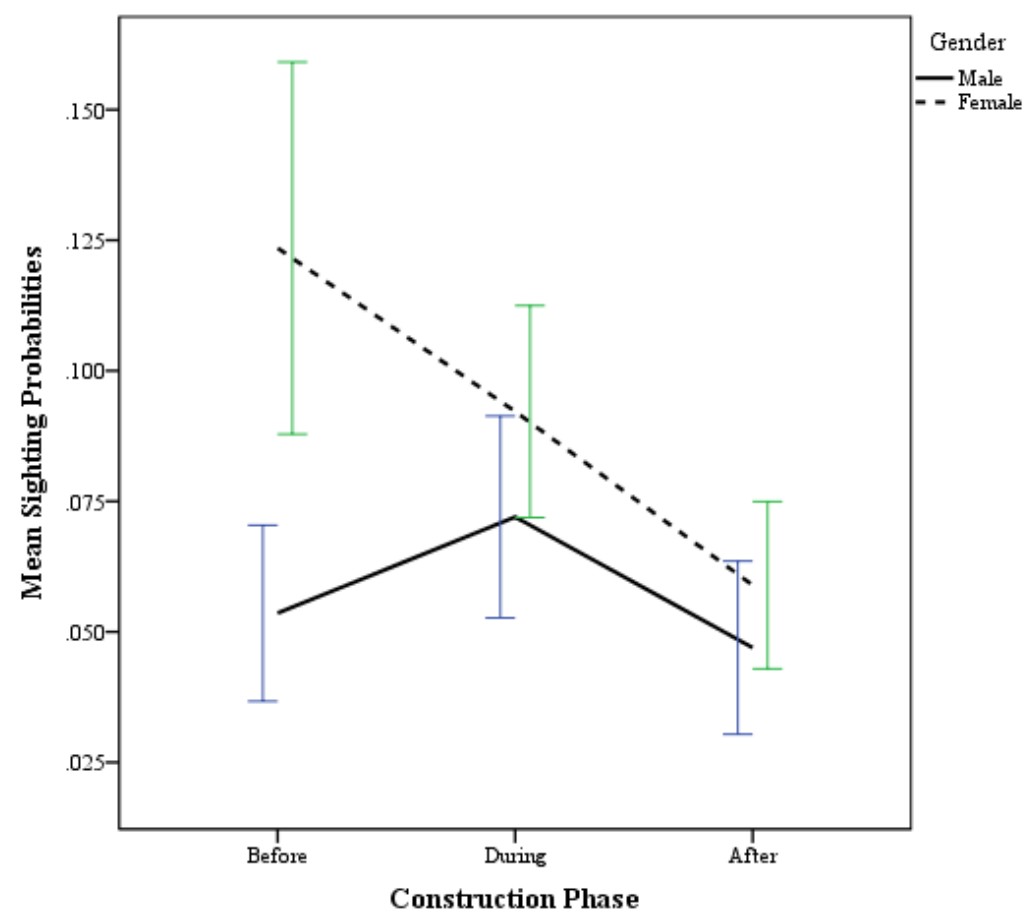

Figure 3. Mean sighting probabilities of adult male $(n=28)$ and female $(n=40)$ free-ranging bottlenose dolphins in John's Pass across three phases of construction, $N=6504$ total sightings. Error bars $\pm 2 \mathrm{SE}$. 
Both main effects were statistically significant, which can be traced to the significant interaction. There was a significant and substantial main effect of construction phase, Wilks Lambda $=0.56, F(2,65)$ $=25.43, p<0.001$, partial eta squared $=0.44$. This main effect of construction reflected the finding that female sighting probabilities declined significantly before construction to after construction. There was also a significant main effect of gender, $F(1,66)=5.72, p=0.02$, partial eta squared $=0.08$, indicating that there was a sex difference in the probability of sighting males and females. This reflected the finding that females were sighted more often before construction than after construction whereas males did not show a significant difference.

In addition to a significant reduction in mean sighting probabilities by females before to after construction, female sightings also showed a statistically significant reduction in variability. The SE bars in Figure 3 show that variability was highest for females before construction started. Box's M statistic revealed that variability in female probabilities before construction was significantly higher than variability in male and female probabilities during construction or after construction, Box's $\mathrm{M}=30.66$, $F(6,22957)=4.84, p<0.001$. Across construction, however, variability in female sightings systematically converged with and then matched male variability values.

This statistical difference in variances may have produced the significance difference in female means revealed by the repeated measures ANOVA. So the ANOVA results were verified with a BrownForsyth test, which controls for different variances (Weaver \& Goldberg, 2011). The Brown-Forsyth test verified the significant difference of more female sightings before construction, Brown-Forsyth $F(1$, $54.504)=12.58, p=0.001$.

\section{Discussion}

Analysis of the effects of potentially harmful anthropogenic activities on free-ranging bottlenose dolphins is a thorny complex of competing variables. This report examined one variable, sighting probabilities, as the proportion of surveys in which a dolphin was sighted before, during and after bridge construction. Construction was a potentially harmful anthropogenic activity involving a five-year bridge replacement project over the John's Pass tidal inlet, an important but very narrow $183 \mathrm{~m}$ bottlenose dolphin corridor connecting the Gulf of Mexico and Intra-Coastal Waterway on Florida's west coast. Only the 68 adult dolphins that had been identified during pilot work and sighted in all three phases of construction were included. The 68 dolphins that were sighted during the eight-year period before, during and after construction are the dolphins with the highest site fidelity to the study area. The sighting probabilities of adult male and female dolphins were compared before, during and after construction to test hypotheses that construction was associated with changes in sighting probabilities, and that changes in sighting probabilities, if they emerged, were associated with a sex difference in sighting probabilities. The sex difference hypothesis was confirmed. The two main findings were that high site fidelity males did not show a change in the likelihood of sightings across construction, but over the same period, high site fidelity females showed a systematic decline in the likelihood of sightings.

In nearby Sarasota, a bridge construction project over a much wider span than the narrow John's Pass bridge construction seemed to have a directly dispersive effect on dolphins, in that dolphin sightings declined significantly during construction but recovered after construction ended (Buckstaff et al., 2013). In John's Pass, there seemed to be a generally dispersive effect for the females but not the males because two different sex-based patterns emerged (Figure 3). For females, the phases of construction were associated with a steady decline in female sightings across construction. For males, the phases of construction were not associated with a systematic decline. Before construction began in John's Pass, high site fidelity females were sighted over twice as often in the study area than were males. This concurs with what is known about sex differences in bottlenose dolphin female and male site fidelity (Wells \& Scott, 1990). During construction, female sightings went down $25 \%$ from before construction. Though the average female sighting rate was still higher than it was for males during construction, it was no longer significantly higher than male probabilities, which did not change. This decline was similar to that reported by Buckstaff et al. (2013). After construction, female sighting went down another $25 \%$ from during construction. As a result, female sighting probabilities after construction virtually matched male 
probabilities, which remained uniformly low across all construction phases. Overall, there was a 50\% reduction in the likelihood of sighting high site fidelity females over the course of the eight-year study. This striking reduction in female sightings is the source of the very strong main effect of construction, which explained $44 \%$ of the variance in sightings.

Compared to the decline in sighting females, males sighting probabilities did not change across construction. The males' inverted U-shaped function in Figure 3 suggests males were differentially attracted to the study area during construction, but average male sighting probabilities did not differ significantly. These differences in the male and female sighting probability patterns accounted for the significant main effect of gender. This was predicted by sex differences in bottlenose dolphin philopatric patterns, and thus supported the sex difference hypothesis.

The sex difference in sightings that was temporally associated with coastal construction may have stemmed in part from sex differences in environmental monitoring and vigilance associated with maternal behavior. Females showed a systematic dispersal from the study area, reflected in their reduced sighting rates and reduced variability in sightings. In contrast, males did not show a similar decline in sightings. This argues that the ecological conditions that correspond to the daily living pressures for males remained relatively unchanged across construction, but that the ecological conditions corresponding to the daily living pressures for females changed across construction. The biggest difference between adult males and females is motherhood. During the time that females showed a systematic dispersal from the study area, the majority were actively engaged in maternal behavior raising 1-4 calves.

Females may be more susceptible to anthropogenic-related disturbances of the environment than males because of their stronger philopatry and more reactive to disturbances because of the greater vigilance associated with rearing young. The acoustic connection between mother and dependent calf, particularly the exchange of individually-identifying signature whistles (Janik \& Slater, 1998), is critical to maintaining their group cohesion (Herzig, 1996; Janik \& Slater, 1998; McCowan \& Reiss, 1995; Sayigh, Tyack, Wells, \& Scott, 1990; Sayigh et al., 1999; Smolker, Mann, \& Smuts, 1993). Anything that interferes with ambient underwater noise levels can compromise maternal care and calf survival. Dolphin mothers may have a greater need for quiet waters than males to maintain acoustic contact with their calves, find the extra food needed to fuel lactation, and to acoustically monitor for predators to herself and her calf. In turn, calves need to be able to hear their mother's whistles to maintain contact with her and to learn the species' acoustic repertoire. Construction noise above ambient levels was not measured in the current study but it clearly occurred (Figure 1). Acoustic data are needed on construction-induced changes to the ambient acoustic environment to understand how such changes may compromise vital ecological conditions. Sofie et al. (2001) showed that dolphin groups which included mother-calf pairs increased their whistling rates significantly in response to the noise of nearby boats, which suggests that even the noise of local boat traffic affects dolphins' group cohesion. They also reported that mother-calf pairs appeared to be the most perturbed by the noise and exhibited an increased need to re-establish vocal contact (Sofie et al., 2001).

The finding that sex differences in sighting probabilities were temporally associated with bridge construction is a necessary but not sufficient finding to implicate bridge construction as an anthropogenic threat. But it nonetheless raises the possibility that construction had a divisive, erosive effect. Male sighting patterns did not change across construction. Before construction began, males were seen half as often as were females. In contrast, females exhibited a slow steady leak rather than an abrupt exodus from the study area. The steady linear decline in sighting high site fidelity females from before to after construction implied that "old habits die hard" among females. This is what one would expect given longterm, year-round female philopatry patterns (Reynolds et al., 2000; Scott et al., 1990). It was also reflected by the few dolphins that continued to use waterways under the Sarasota construction area reported by Buckstaff et al. (2013). The idea that old habits die hard was also reported for bowhead whales (Richardson et al., 1985; Schick \& Urban, 2000) as well as bottlenose dolphins exposed to construction activities. For bottlenose dolphins (Buckstaff et al., 2013; Moore et al., 2006), the density of dolphins in waterways adjacent to bridge construction decreased but did not evaporate during construction, indicating that the waterway remained an important dolphin corridor. After construction in 
the Buckstaff study, dolphin density increased significantly. In the current study, John's Pass dolphins have not shown any sign of a similar return to old habits in the four years after construction ended (as of this writing in the summer of 2014).

Given their presence and numbers, John's Pass dolphins are a constituent part of the carrying capacity and health of the Boca Ciego estuarine ecosystem. The significance of a decline in high site fidelity females for the reproductive viability and long-term survival of the John's Pass dolphin community has yet to be determined. Bottlenose dolphins reproduce slowly, so effects may not be apparent for several years (Wilson, Hammond, \& Thompson, 1999). Given that a dolphin community is largely maintained by female philopatry (Duffield \& Wells, 2002), a continued leak of females would clearly threaten the long-term viability of the John's Pass dolphin community.

In addition to suggesting a sex difference in cetacean response to anthropogenic coastal activities, this study confirms Wilson et al.'s (1999) recommended minimum of eight years of study that are needed to adequately estimate the impact of anthropogenic activities on bottlenose dolphins. What constitutes an adequate amount of time to monitor potential anthropogenic effects, however, is also contingent upon the duration of potentially harmful human activities, the extent of their imputed ecological disruptiveness and whether affected wildlife can avoid them.

These findings also confirm Connor et al.'s (2000) claim that bottlenose dolphins are well-suited to the role of environmental sentinels for coastal habitats, but also introduce the possibility that the sentinel role may not be as simple as it seems - if sex differences are involved. Moreover, geographicallylocalized anthropogenic activities like John's Pass Bridge construction makes it possible to relate specific activities to particular population units. There is ample opportunity to continue research. In 2011, the US Department of Transportation's Federal Highway Administration (FHWA) classed 4000 of Florida's bridges as deficient, structurally deficient, or functionally obsolete, which provides an estimate of the number of current and scheduled bridge construction projects, many of which span waters where dolphins abound.

\section{Acknowledgements}

I gratefully acknowledge Randy Wells, Frans de Waal and Martha Jane Caldwell for helpful comments on this manuscript, John Heidemann for equipment maintenance and construction images, and Ann Shemaka for efficient provision of Florida Dept of Transportation bridge statistics. This study was conducted under NOAA permits GA1088-1815 and 16299.

\section{References}

Becker, M. L., \& Ross, M. A. (1999). A model study of Boca Ciega Bay, John's Pass, and Blind Pass. Tampa (FL). University of South Florida, Center for Modeling Hydrologic and Aquatic Systems, Department of Civil and Environmental Engineering, Publication Report No. CMHAS.FDOT.99.01.

Bowles, A. E., Smultea, M., Würsig, B., DeMaster, D. P., \& Palka, D. (1994). Relative abundance and behavior of marine mammals exposed to transmissions from the Heard Island Feasibility Test. Journal of the Acoustical Society of America, 96, 469-84.

Buckstaff, K. C., Wells, R. S., Gannon, J. G., \& Nowacek, D. P. (2013). Responses of bottlenose dolphins (Tursiops truncatus) to construction and demolition of coastal marine structures. Aquatic Mammals, 39, 174-186. doi: 10.1578/AM.39.2.2013.174

Connor, R. C., Wells, R., Mann, J., \& Read, A. (2000). The bottlenose dolphin: Social relationships in a fissionfusion society. In J. Mann, R. C. Connor, P. L. Tyack, \& H. Whitehead (Eds.), Cetacean Societies. Pp. 91126. Chicago: University of Chicago Press.

Cosens, S. E., \& Dueck, L. P. (1993). Icebreaker noise in Lancaster Sound, N.W.T., Canada: Implications for marine mammal behavior. Marine Mammal Science, 9, 285-300.

Duffield, D. A., \& Wells, R. S. (2002). The molecular profile of a resident community of bottlenose dolphins, Tursiops truncatas. In C. J. Pfeiffer (Ed.). Molecular and Cell Biology of Marine Mammals. Pp. 3-11. Melbourne, FL: Krieger Publishing Co. 
Fazioli, K. L. (1999). Distribution, relative abundance, and community structure of coastal bottlenose dolphins (Tursiops truncatus) in the Gulf of Mexico off Sarasota, FL (unpublished master's thesis). University of California, Santa Cruz.

Feinholz, D. M. (1995). Northern range extension, abundance, and distribution of Pacific coastal bottlenose dolphins (Tursiops truncatus gilli) in Monterey Bay, California. Abstracts, $11^{\text {th }}$ Biennial Conference on the Biology of Marine Mammals. Orlando, FL.

FHWA. (2011). Florida Highway Administration. http://www.fhwa.dot.gov/bridge/deficient.cfm

Finley, K. J., Miller, G. W., Davis, R. A., \& Greene, C. R. (1990). Reactions of belugas, Delphinapterus leucas, and narwhals, Monodon monoceros, to ice-breaking ships in the Canadian high arctic. Canadian Bulletin of Aquatic Sciences, 224, 97-117.

Finneran. J. J., Schlundt, C. E., Carder, D. A., Clark, J. A., Young, J. A., Gaspin, J. B., \& Ridgway, S. H. (2000). Auditory and behavioral responses of bottlenose dolphins (Tursiops truncatus) and a beluga whale (Delphinapterus leucas) to impulsive sounds resembling distant signatures of underwater explosions. Journal of the Acoustical Society of America, 108, 417-431.

Frantzis, A. (1998). Does acoustic testing strand whales? Nature, 392, 29.

Fulling G. L., Mullin, K. D., \& Hubard, C. W. (2007). Bottlenose dolphins (Tursiops truncatus): Northern Gulf of Mexico continental shelf stock. NOAA Tech. Memo. NOAA NMFS-EFC-539.

Hammond, P. S., Mizroch, S. A., \& Donovan G. P. (1990). Individual recognition of cetaceans: Use of photoidentification and other techniques to estimate population parameters. Reports of the International Whaling Commission, Special Issue 12. Cambridge, UK: International Whaling Commission.

Herzig, D. L. (1996). Vocalizations and associated underwater behavior of free-ranging Atlantic spotted dolphins, Stenella frontalis, and bottlenose dolphins, Tursiops truncatus. Aquatic Mammals, 22, 61-79.

Hubard, C. W., \& Schwartz, S. (2002). Gulf of Mexico bottlenose dolphin stock identification workshop. March 1415, 2000. Sarasota, FL. NOAA Tech. Memo. NMFS-SEFSC-473.

Janik, V., \& Slater, P. J. B. (1998). Context-specific use suggests that bottlenose dolphin signature whistles are cohesion calls. Animal Behaviour, 56, 829-838.

LGL \& Greeneridge. (1986). Reactions of beluga whales and narwhals to ship traffic and ice-breaking along ice edges in the eastern Canadian High Arctic: 1982-1984. Environmental Studies, 37. Indian and Northern Affairs Canada, Ottawa, Ontario.

Lesage, V., Barrette, C., Kingsley, M. C. S., \& Sjare, B. (1999). The effect of vessel noise on the vocal behavior of belugas in the St. Lawrence River estuary, Canada. Marine Mammal Science, 15, 65-84.

McCowan, B., \& Reiss, D. (1995). Maternal aggressive contact vocalizations in captive bottlenose dolphins (Tursiops truncatus): Wide-band, low frequency signals during mother/aunt-infant interactions. Zoo Biology, 14, 293-309.

Malme, C. I., \& Miles. P. R. (1985). Behavioral responses of marine mammals (gray whales) to seismic discharge (Proceedings of the Workshop on Effects of Explosives Use in the Marine Environment. Halifax. Pp 253280). Nova Scotia Technical Report No. 5 Canadian Oil and Gas Lands Administration Environmental Protection Branch, Ottawa, Ontario. 398 pp.

Mann, J. (1999). Behavioral sampling methods for cetaceans: A review and critique. Marine Mammal Science, 15, $102-122$.

Moore, K. C., Wells, R. S., Gannon, J. G., \& Nowacek, D. P. (2006). Responses of bottlenose dolphins to construction and demolition of underwater structures. Mote Marine Laboratory Technical Report Number 1081. Final Report for Aware No. MML-03-03.

Müeller, M., Boutiere, H., Weaver, A., \& Candelon, N. (1998). Ethogram of the bottlenose dolphin, with special reference to solitary and sociable dolphins. Vie Milieu (Life and Environment), 48, 89-104.

Reynolds, J. E., Wells, R. S., \& Eide, S. D. (2000). The bottlenose dolphin. Gainesville, FL: University of Florida Press.

Richardson, W. J., Fraker, M. A., Würsig, B., \& Wells, R. S. (1985). Behaviour of bowhead whales, Balaena mysticetus, summering in the Beaufort Sea: Reactions to industrial activities. Biological Conservation, 32, 195-230.

Richardson, W. J., Greene Jr., C. R., Malme, C. I., \& Thomson, D. (1995). Marine mammals and noise. San Diego: Academic Press.

Samuels, A., \& Tyack, P. (2000). Flukeprints. A history of studying cetacean societies. In. J. Mann, R. C. Connor, P. L. Tyack, \& H. Whitehead, (Eds.), Cetacean societies. Pp. 9-44. Chicago: University of Chicago Press. 
Sayigh, L., Tyack, P., Wells, R. S., \& Scott, M. D. (1990). Signature whistles of free-ranging bottlenose dolphins Tursiops truncatus: Stability and mother-offspring comparisons. Behavioral Ecology and Sociobiology, 26, 247-260.

Sayigh, L., Tyack, P., Wells, R. S., Solow, A. R., Scott, M. D., \& Irvine, B. (1999). Individual recognition in wild bottlenose dolphins: A field test using playback experiments. Animal Behaviour, 57, 41-50.

Schick, R. S., \& Urban, D. L. (2000). Spatial components of bowhead whales (Balaena mysticetus) distribution in the Alaskan Beaufort Sea. Canadian Journal of Fisheries and Aquatic Science, 57, 2193-2200.

Scott, M. D., Wells, R. S., \& Irvine, A. B. (1990). A long-term study of bottlenose dolphins on the west coast of Florida. In S. Leatherwood and R. R. Reeves (Eds), The bottlenose dolphin. Pp. 235-244. San Diego: Academic Press.

Sellas, A. B., Wells, R. S., \& Rosel, P. E. (2005). Mitochondrial and nuclear DNA analyses reveal fine scale geographic structure in bottlenose dolphins (Tursiops truncatus) in the Gulf of Mexico. Conservation Genetics, 6, 715-728. doi: 10.1007/s10592-005-9031-7

Shane, S. H., Wells, R. S., \& Würsig, B. (1986). Ecology, behavior and social organization of the bottlenose dolphin: A review. Marine Mammal Science, 2, 34-63.

Smolker, R. A., Mann, J., \& Smuts, B. (1993). Use of signatures whistles during separations and reunions by wild bottlenose dolphin mothers and infants. Behavioral Ecology and Socioecology, 33, 393-402.

Sofie, M., van Parijs, S. M., \& Corkeron, P. J. (2001). Boat traffic affects the acoustic behavior of Pacific humpback dolphins, Sousa chinensis. Journal of the Marine Biological Association of the UK, 81, 533-538. doi: 10.1017/S0025315401004180

Todd, S., Stevick, P., Lien, J., Marques, F., \& Ketten, D. (1996). Behavioural effects of exposure to underwater explosions in humpback whales (Megaptera novaeangliae). Canadian Journal of Zoology, 74, 1661-1672.

Urian, K. W., Hohn, A. A., \& Hansen, L. J. (1999). Status of the photo-identification catalog of coastal bottlenose dolphins of the western North Atlantic: Report of a workshop of catalog contributors. NOAA Technical Memorandum NMFS-SEFSC-425. 24 pp.

Weaver, A., \& Goldberg, S. (2011). Clinical biostatistics and epidemiology made ridiculously simple. Miami, FL: MedMaster Pub.

Wells, R. S. (2003). Dolphin social complexity: Lessons from long-term study and life history. In F. B. M. de Waal \& P. L. Tyack (Eds.), Animal social complexity. Pp. 32-56. Cambridge, MA: Harvard University Press.

Wells, R. S., Bassos, K. M., Urian, K. W., Carr, W. J., \& Scott, M. D. (1996). Low-level monitoring of bottlenose dolphins, Tursiops truncatus, in Charlotte Harbor, Florida 1990-1994. NOAA Technical Memorandum. NMFS-SEFSC-384.

Wells, R. S., Hansen, L. J., Baldridge, A., Dohl, T. P., Kelly, D. L., \& Defran, R. H. (1990). Northward extension of the range of bottlenose dolphins along the California coast. In S. Leatherwood \& R.R. Reeves (Eds.), The bottlenose dolphin. Pp. 421-434. San Diego: Academic Press.

Wells, R. S., \& Scott, M. D. (1990). Estimating bottlenose dolphin population parameters from individual identification and capture-release techniques. In P. S. Hammond, S. A. Mizroch, \& G. P. Donovan (Eds.), Individual recognition of cetaceans: Use of photo-identification and other techniques to estimate population parameters (pp. 407-416). Reports of the International, Whaling Commission, Special Issue 12. Cambridge, UK: International Whaling Commission.

Wells, R. S., Urian, K. W., Read, A. J., Bassos, M. K., Carr, W. J., \& Scott, M. D. (1996). Low-level monitoring of bottlenose dolphins, Tursiops truncatus, in Tampa Bay, Florida 1988-1993. NOAA Technical Memorandum. NMFS-SEFSC-385.

Whitehead. H., Reeves, R. R., \& Tyack, P. L. (2000). Science and the conservation, protection and management of wild cetaceans. In J. Mann, R. C. Connor, P. L. Tyack, \& H. Whitehead, (Eds.), Cetacean societies. PP. 308-332. Chicago: University of Chicago Press.

Wilson, B., Hammond, P. S., \& Thompson, P. M. (1999). Estimating size and assessing trends in a coastal bottlenose dolphin population. Ecological Applications, 9, 288-300.

Würsig, B., \& Evans, P. G. H. (2001). Cetaceans and humans: Influence of noise. In P. G. H. Evans \& J. A. Raga (Eds.), Marine mammals, biology and conservation (pp. 565-587). New York: Kluwer Academic/Plenum Publishers.

Würsig, B., Greene Jr., C. R., \& Jefferson T. A. (2000). Development of an air bubble curtain to reduce underwater noise of percussive piling. Marine Environmental Research, 49, 79-93.

Würsig, B., \& Lynn, S. K. (1996). Movements, site fidelity, and respiration patterns of bottlenose dolphins on the Central Texas Coast. NOAA Technical Memorandum NMFS-SEFSC-383. 
Weaver 13

Würsig, B., \& Würsig, M. (1977). The photographic determination of group size, composition and stability of coastal porpoises (Tursiops truncatus). Science, 198, 755-756. 